\title{
Research on the technical requirements standard of the services of environmental protection facilities operating organization for assessment
}

\author{
Huang Jin $^{1,}{ }^{*}$,Zhang Xiaoxin ${ }^{l}$, Xu Bingsheng ${ }^{1}$, Lin Ling ${ }^{1}$ \\ ${ }^{1}$ China National Institute of Standardization, 100191 Beijing, China
}

\begin{abstract}
The service ability and quality for the environmental protection facilities operating organization have the direct bearing on the achievements of ecological civilization construction and environmental quality improvement goals. This article discussed the significance of the research on the technical requirements national standards of the services of environmental protection facilities operating organization for assessment, expounded the classification and scope of the environmental protection facilities operating organization, as well as the assessment technical requirements, which included the assessment principle, basic requirements, the evaluation index requirements, test and calculation method, statistics and evaluation classification, etc. The development and implementation of the standard will contribute to the promoting of the operating level for the domestic environmental protection facilities.
\end{abstract}

\section{Background}

The environmental protection facilities operation is an important part of the environmental protection service industry. With reform of operation licensing of environmental pollution control facilities in 2014, the classification and grading standard for the operation qualification of environmental pollution control facilities are abolished, besides, the third-party management service model of environmental pollution is widely used at the present. The relevant evaluation technical standards are required for self-discipline of the environmental protection facilities operation and service industry is urgently needed for standardizing and guiding. Therefore, proposed by the National Development and Reform Commission, National Standardization Management Committee formally approved Technical Requirements for Environmental Protection Facilities Operational Organization Service Evaluation with decree No. 52 (2015) of Standardization Administration of the People's Republic of China, National Environmental Protection Industry Standardization Technical Committee (SAC/TC275) is authorized of the development of the standard.

2 Meaning of developing technical requirements standard of the services of environmental protection facilities operating organization for assessment
2.1 Supporting the implementation of the relevant policies of the national environmental protection industry with standardization

During the period from 12th Five-Year Plan to 13th Five-Year Plan, a series of new policies, systems and plans related to environmental protection industry were released to improve the ecological environment quality and promote the development of ecological civilization construction and environmental protection. As specified in 13th Five-Year Plan Outline, "we shall expand the supply of environmental protection products and services, encourage the development of professional service of environmental protection and promote the third-party governance, environment monitoring and consultation of environmental pollution." The Development Plan of Energy Saving and Environmental Protection Industry During 13th Five-Year Plan Period proposed that "we shall provide innovative environmental protection service model, promote the third-party governance of environmental pollution, environmental monitoring and consultation services". Opinion on the Implementation of the Third-party Governance of Environmental Pollution Issued by General Office of the State Council (GNF [2014] No. 69) specified that "By 2020, the thirdparty governance in key areas will greatly progress, such as environmental public facilities and industrial parks. The efficiency of pollution control and the specialization level are obviously improved; the formats and patterns of third-party governance becomes mature and a lot of environment services companies with great technical ability, high operation and management level, good credit and international competitiveness are emerged." In

\footnotetext{
* Corresponding author: huangjin@cnis.gov.cn
} 
order to speed up and standardize the third-party governance of environmental pollution, the Ministry of Environmental Protection issued Opinion of the Ministry of Environmental Protection on Promoting Third-party Governance of Environmental Pollution (HGCH [2017] No. 172) in August, 2017, and proposed the guideline that "guided by marketization, specialization and industrialization of environmental pollution control, we shall promote to establish new mechanism of pollution control combining the payment made by polluters, thirdparty governance and pollutant discharging permit system, continuously improving the governance efficiency and specialization level", specifying that "the operation of pollution control facilities shall be standardized. The company discharging the pollutant and third-party governance institutes shall ensure the normal operation of the environmental protection facilities. The continuous stable operation of pollution control equipment and facilities and monitoring equipment facilities shall be covered in the key points of environment monitoring." With the reform of the ecological civilization system and complete implementation of Action Plan for Air Pollution Prevention and Control, Action Plan for Water Pollution Prevention and Control and Action Plan for Soil Pollution Prevention and Control, the implementation of new environmental protection policy above proposes the practical and urgent demand for development of technical standards for service organization service evaluation of environmental protection facilities. With the development of the standard, it will provide standardized technical support of implementation of a series of environmental protection services related policy at the present.

\subsection{Improving the service level of environmental protection facilities operating organization is significant to realize the sustainable and effective emission reduction and establish the evaluation system}

The professionalization, socialization, marketization, normalization and standardized management of environmental protection facilities operation are effective measures to ensure the facilities operation effect, reduce the operation costs and ensure the environmental investment profits. The development and implementation of technical standards for operation service organization evaluation of environmental protection facilities are the important basis to improve the management as mentioned above. The emission can be continuously and effectively reduced only when the service level of environmental protection facilities operating organization by the standardized method.

The third-party governance of environmental pollution is the important way for the specialization and industrialization of the construction and operation of environmental protection facilities, effective measures to promote the environment service industry development, as well as the significant method to solve the economic transformation and upgrade and make the manufacturers focusing on production. The implementation of thirdparty governance of environmental pollution could fundamentally change the environmental protection governance structure and transfer the economic structure and development mode, to establish a new pattern with government, enterprise and "third-party governance" developing together. The development of technical requirement for service organization evaluation of environmental protection facilities demands for the national standard to standardize the facility operating organization with disqualified governance effect, weak technical service capacity, low operation management and poor comprehensive credit. It will fill the gap of lack of management standard for domestic environmental protection facilities operating organization service evaluation. It is important for the environmental protection service franchisee or entrustment operation, performance credit evaluation of service organization, service bidding purchasing, service organization integrity establishment, to build the environmental protection facilities operating organization service evaluation system, credit accumulation system and blacklist system in the future in our country.

\section{Classification and scope of environmental protection facilities operating organization}

The environmental protection facilities operation facilities refer to the organizations that provide the social paid service specializing in the operation, maintenance and management of domestic environmental protection facilities in order to prevent and control the environmental pollution generated by the industry, business and service industries in the production, or offer the paid service of operation and management of environmental protection facilities based on the contract signed by both parties. According to the segments of the environmental protection in our country, the standard includes 9 types, such as urban sewage treatment, industrial wastewater treatment, rural sewage treatment, dust removal and desulfurization denitration, industrial organic waste gas treatment, domestic waste treatment, industrial solid waste disposal and environment remediation while the operating organizations that treat the noise and radiation are excluded in the standard. The operating facilities corresponding to various environmental protection facilities operating organizations are specified as following:

(1) Urban sewage treatment: Centralized urban sewage treatment facilities; decentralized domestic sewage treatment facilities for residential districts, public buildings, hotels, hospitals and enterprises and institutions.

(2) Industrial wastewater treatment: Wastewater treatment facilities for various industrial enterprises; centralized wastewater treatment facilities for various industrial parks; landfill leachate treatment facilities.

(3) Rural sewage treatment: Centralized rural domestic sewage treatment facilities; decentralized rural domestic sewage treatment facilities. 
(4) Dust removal and desulfurization denitration: purification facility of $\mathrm{SO}_{2}, \mathrm{NOx}$, particles (soot and dust) in exhaust of industrial boilers, power plant boilers, industrial furnaces (smelting furnaces, coke ovens, sintering machines, cement kilns, etc.).

(5) Industrial organic waste gas treatment: purification facility of gas pollutant (including stink) with volatile organic compounds in industry and the fume cleaning facilities in catering industry.

(6) Domestic waste treatment: facilities treating the solid wastes generated in the daily life or activity, and the domestic rubbish specified in law and regulations, including: household garbage, market and commercial waste, public waste, street garbage and wastes generated from the enterprises and institutions.

(7) Industrial solid waste disposal: facilities treating the residue, dust and other wastes generated in the industrial production, including: blast furnace slag, steel slag, red mud, nonferrous slag, fly ash, coal cinder, sulphuric acid residue, waste gypsum, desulphurization ash, carbide slag and salt mud. Excluding the industrial hazardous solid waste, that is, hazardous solid waste.

(8) Environment remediation: special facilities for soil remediation, smelly black water and watershed management.

(9) Environment monitoring: water quality monitoring, environmental air and gas pollution source monitoring, noise monitoring, soil pollution monitoring and biological monitoring special facilities.

\section{Equations and mathematics Technical requirements for environmental protection facilities operating organization service evaluation}

\subsection{Establishing the evaluation principle}

- The standard combines the basic requirements and evaluation index requirements to evaluate various environmental protection facilities operating organization service. The basic requirements must be met, otherwise the service shall not be evaluated, and the evaluation index requirements shall be measurable and verifiable. With the progress of science and technology and the industry development, the basic requirements and the evaluation index requirements shall be expanded continuously.

- The basic requirements mainly involve the management system, financial, compliance, staffing situation, detection ability, emission standards of environmental protection facilities operating organization. The key evaluation index with significant impact on the organization basic ability and facility operation effect according to the characteristics of various types of environmental protection facilities operating organization service. The selection of the index shall be considered in comprehensive and simple way with emphasized key point, scientific and reasonable, with great feasibility.

\subsection{Basic Requirements}

The basic requirements for the operating organization evaluation of environmental protection facilities include the following:

- The environmental protection facilities operating organization shall have the ability to independently assume the legal responsibilities.

- The environmental protection facilities operating organization shall have healthy financial status and profitability.

- The environmental protection facilities operating organization shall have the management ability, pass the quality management system certification, environmental management system and occupational health and safety management system certification, keep the complete and effective records of the operational activities.

- The environmental protection facilities operating organization shall have the ability to treat the environmental emergencies and make response, with the feasible emergency response plan which can be effective implemented in operational services process.

- The environmental protection facilities operating organization shall have a certain quantity of the professional and technical personnel and operators onsite who can meet the requirements. The profession and ability of the professional and technical staff shall effectively cover all the aspects in environmental protection facilities in normal operation. The operators shall be trained and obtain the qualification certificate of examination, with the ability of normal operation and maintenance of corresponding environmental protection facilities, and to deal with and solve the emergencies.

- The environmental protection facilities operating organization shall have its own laboratory, and the measuring instrument shall be configured to meet the detection requirements for the regular and main pollutants within the operation service scope. The testing personnel shall have relevant qualifications, master the testing methods, standards and procedures.

- The environmental protection facilities operating organization shall ensure that the operation of the facilities meet the national and local emission standards and the requirements of the contract and the discharging permit.

\subsection{Evaluation index requirements}

The evaluation index requirements involve the establishment of evaluation index system of environmental protection facilities operating organization, the setup of weights of evaluation index at various levels, and the evaluation methods.

The evaluation indexes are divided into two categories: the organization basic ability and the facilities operation effect, with 100 points in total. The organization basic ability includes 3 Class A indexes, that is human resources and research and development capacity, pollutant detection ability, quality, environment and safety management ability, with 30 points in total. The facilities operation effect includes 5 Class A indexes about environmental protection performance, resource 
and energy consumption, technology and economic performance, operation management and equipment status, with 70 points in total. Each Class A index can be subdivided into several Class B indexes. The standard sets up 8 Class A indexes and 26 Class B indexes.

Table 1. Index requirements for evaluation of environmental protection facilities operational organizational services. methods are determined as shown in Table 1.
According to the overall level and technology advancement of the existing environmental protection facilities operating organization service, the Class A and Class B indexes and their weights and evaluation

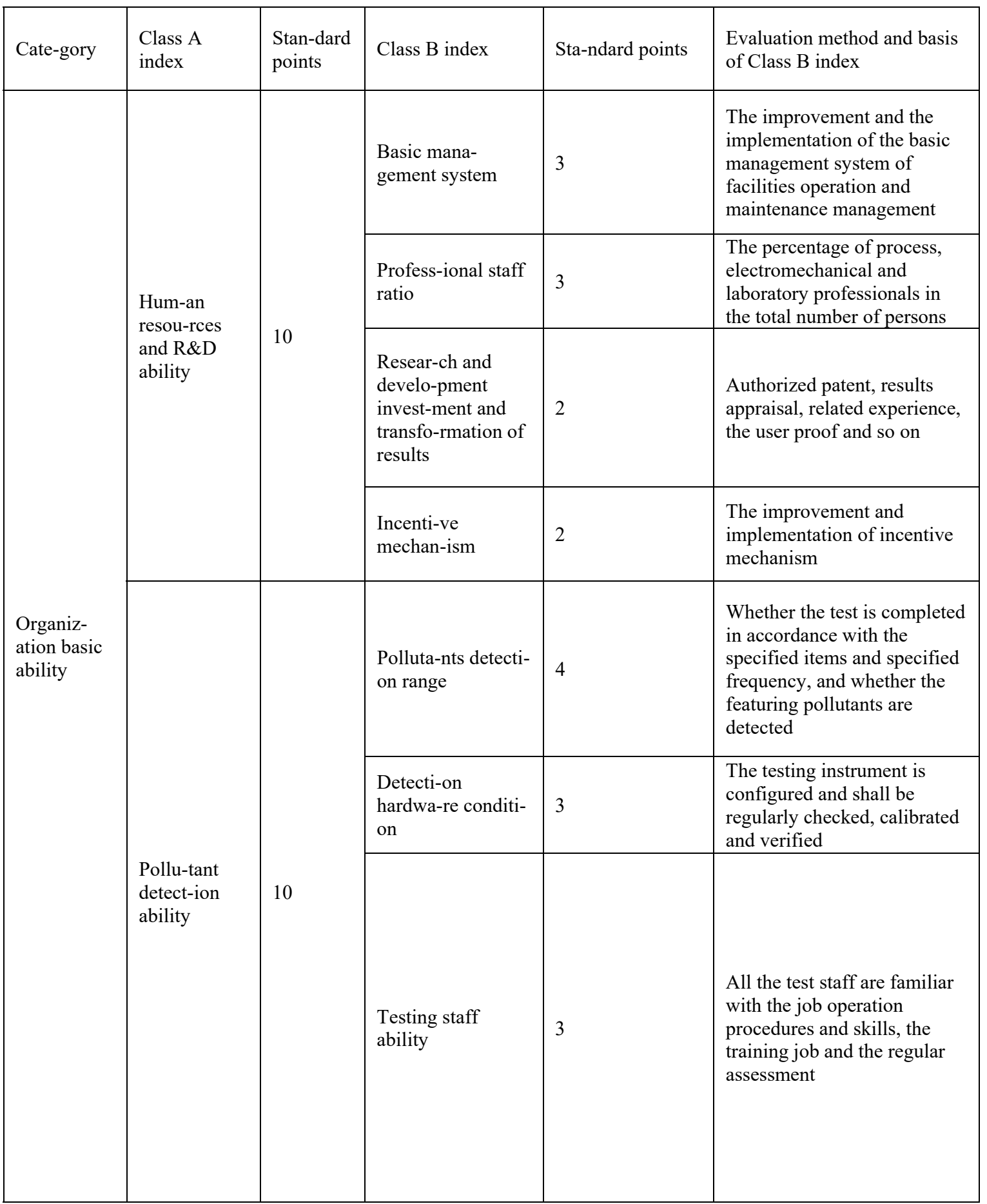




\begin{tabular}{|c|c|c|c|c|c|}
\hline & \multirow{4}{*}{$\begin{array}{l}\text { Quali-ty, } \\
\text { envir-onme- } \\
\text { nt and safety } \\
\text { mana-geme- } \\
\text { nt ability }\end{array}$} & \multirow{4}{*}{10} & $\begin{array}{l}\text { Emerg-ency and } \\
\text { respons-e to } \\
\text { enviro-nmental } \\
\text { emerge-ncies }\end{array}$ & 3 & $\begin{array}{l}\text { The special emergency } \\
\text { response procedures, plans, } \\
\text { training plans and records of } \\
\text { the emergency response to } \\
\text { environmen-tal emergency; } \\
\text { the response to existing } \\
\text { environment emergencies }\end{array}$ \\
\hline & & & $\begin{array}{l}\text { Related party } \\
\text { satisfaction }\end{array}$ & 2 & $\begin{array}{l}\text { Percentage of satisfaction } \\
\text { assessment of users }\end{array}$ \\
\hline & & & People compla-int & 2 & $\begin{array}{l}\text { The environmental petition, } \\
\text { complaint, measures to be } \\
\text { taken and cause a negative } \\
\text { social impact }\end{array}$ \\
\hline & & & $\begin{array}{l}\text { Fire control and } \\
\text { labor safety }\end{array}$ & 3 & $\begin{array}{l}\text { Whether the fire control and } \\
\text { labor safety measures are } \\
\text { complete, whether there are } \\
\text { corresponding fire control } \\
\text { and labor safety management } \\
\text { organizations, training plans } \\
\text { and records, whether there } \\
\text { are loopholes in the } \\
\text { management of special } \\
\text { equipment and mandatory } \\
\text { inspection items, and the } \\
\text { labor safety protection of } \\
\text { operators. }\end{array}$ \\
\hline \multirow{4}{*}{$\begin{array}{l}\text { Facility } \\
\text { operation } \\
\text { effect }\end{array}$} & \multirow{2}{*}{$\begin{array}{l}\text { Envir- } \\
\text { onmental } \\
\text { prote-ction } \\
\text { perfo-rmance }\end{array}$} & \multirow[t]{2}{*}{20} & $\begin{array}{l}\text { Average annual } \\
\text { polluta-nt reaching } \\
\text { standard }\end{array}$ & 10 & $\begin{array}{l}\text { Whether the monitoring } \\
\text { index in the organization on } \\
\text { normal operation days and } \\
\text { regular monitoring index } \\
\text { developed by the } \\
\text { environmental protection } \\
\text { department are met }\end{array}$ \\
\hline & & & $\begin{array}{l}\text { Second-ary } \\
\text { polluti-on control }\end{array}$ & 10 & $\begin{array}{l}\text { Whether the secondary } \\
\text { pollutants discharging meet } \\
\text { the standard, whether the } \\
\text { secondary pollution is caused }\end{array}$ \\
\hline & \multirow{2}{*}{$\begin{array}{l}\text { Reso-urce } \\
\text { and energy } \\
\text { cons-umpt- } \\
\text { ion }\end{array}$} & \multirow[t]{2}{*}{15} & $\begin{array}{l}\text { Annual unit } \\
\text { polluta-nt disposal } \\
\text { power consu- } \\
\text { mption }\end{array}$ & 5 & $\begin{array}{l}\text { Whether the power } \\
\text { consumption in the operation } \\
\text { process is accurately } \\
\text { measured, whether the } \\
\text { electricity saving measures } \\
\text { are optimized, the measures } \\
\text { are in place, and the } \\
\text { electricity consumption is } \\
\text { obvious }\end{array}$ \\
\hline & & & $\begin{array}{l}\text { Annual unit } \\
\text { polluta-nt treatme- } \\
\text { nt of water consu- } \\
\text { mption }\end{array}$ & 5 & $\begin{array}{l}\text { Whether the water } \\
\text { consumption in the operation } \\
\text { process is accurately } \\
\text { measured, whether the water } \\
\text { saving measures are } \\
\text { optimized, the measures are } \\
\text { in place, and the water } \\
\text { consumption is obvious }\end{array}$ \\
\hline
\end{tabular}




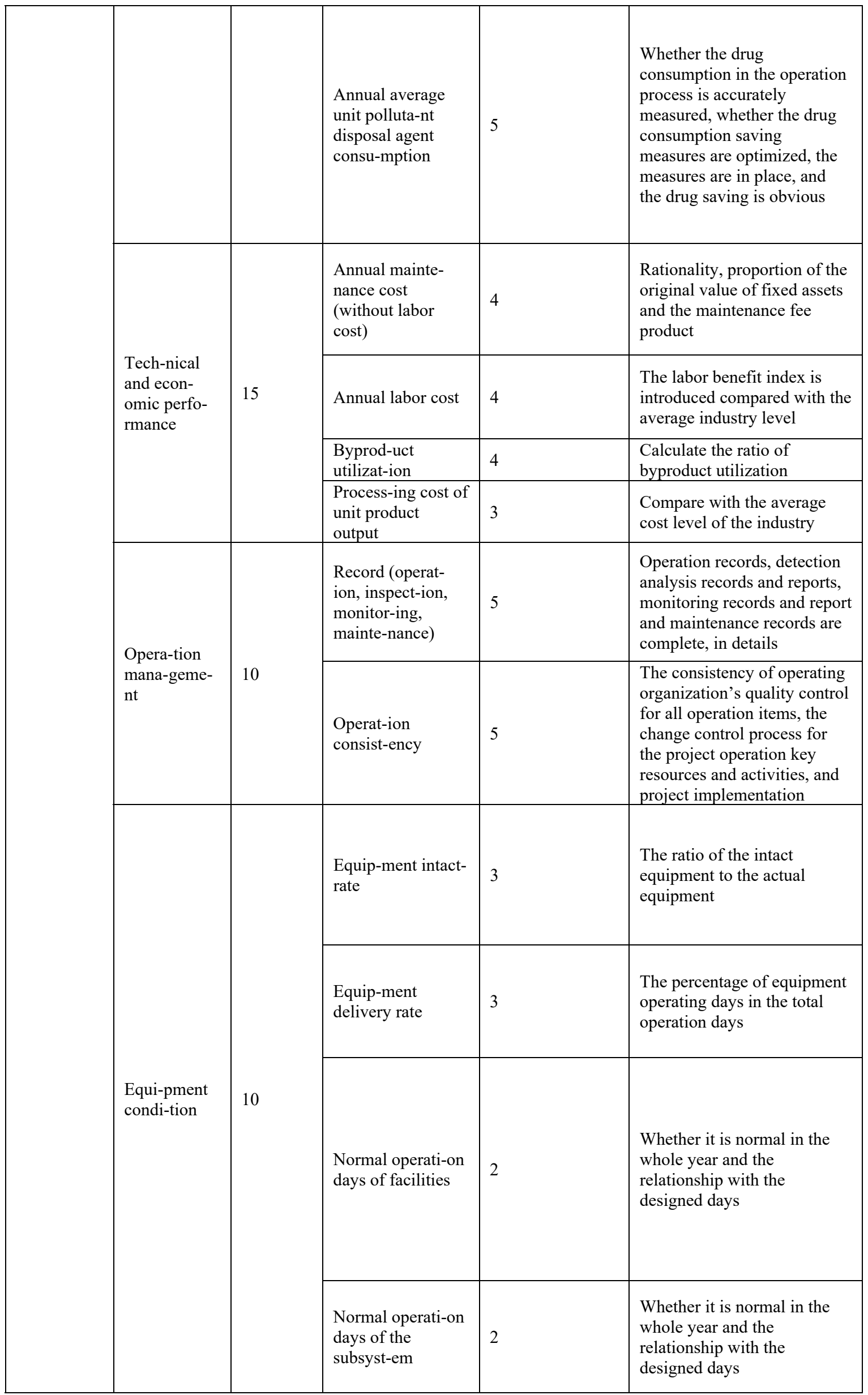




\subsection{Test method, calculation method, statistics and evaluation classification of environmental protection facilities operating organization service evaluation}

The standard stipulates that the tests of all evaluation indexes shall be tested according to the standards, and the minimum test cycle and frequency shall be defined. The load cycle and equipment reliability shall be considered in the test plan.

The standard specifies the professionals proportion, related parties satisfaction, power consumption, water consumption, pollutant treatment drug consumption for annual average unit, annual maintenance fee, annual labor fee, artificial benefit index, by-product utilization, equipment intact rate, equipment operation rate and other evaluation index calculation formula.

The total points of the environmental protection facilities operating organization service elevation are 100 points. The organization should account the total points of the Class II for the environmental protection facilities operating organization service elevation. The environmental protection facilities operating organization is evaluated only when it meets the standard basic requirements, and the evaluation can be divided into three grades : the grade 1 is More than 90 points , grade 2 is 75 to 90 points, and grade 3 is 60 to 75 points.

\section{Conclusion}

The national standard of technical requirement of environmental protection facilities operating organization service evaluation can be used as standard basis for the standardization and self-discipline of technical service ability in the environmental protection facilities operation industry, and it also can be used as the access condition and judgment criteria for the environmental protection facilities services market, so as to ensure the development of the third party evaluation of the operation service, effective maintenance for the operating service market order, fully reflecting the concept of leading environmental protection service quality improvement with advanced management evaluation standard.

\section{Acknowledgment}

This work was supported by the National Key R\& D Program of China (2018YFF0213203).

\section{References}

1. $\mathrm{Xu}$ Bingsheng, Lin Ling, Huang Jin. Earth and Environmental Science. 94 (2017).

2. T/CAEPI 2 The technical requirement for operation and maintenance of environmental protection facilities. (2016).
3. GB/T34605 Technical requirements of operation performance assessment for coal-fired flue gas desulfurization installation. (2017).

4. GB/T34607 Performance assessment of the desulfurization equipment and dust collector for sintering flue gas from iron and steel industry. (2017).

5. GB/T34340 Technical requirements of operation performance assessment for coal-fired flue gas denitration installation. (2017). 